\title{
"Evaluation of systematic risk, corporate governance, and cash holdings: evidence from Indonesia"
}

\begin{tabular}{ll} 
& Musdalifah Azis (i) \\
Michael Hadjaat & $\begin{array}{l}\text { Rositawati } \\
\text { Dio Caisar Darma (i) } \\
\text { AUTHORS }\end{array}$ \\
& $\begin{array}{l}\text { Musdalifah Azis, Michael Hadjaat, Rositawati and Dio Caisar Darma (2021). } \\
\text { Evaluation of systematic risk, corporate governance, and cash holdings: } \\
\text { evidence from Indonesia. Economics of Development, 20(1), 35-45. } \\
\text { doi:10.21511/ed.20(1).2021.04 }\end{array}$ \\
\hline ARTICLE INFO & http://dx.doi.org/10.21511/ed.20(1).2021.04 \\
\hline DOI & Friday, 20 August 2021 \\
\hline RELEASED ON & Wednesday, 25 November 2020 \\
\hline RECEIVED ON & Tuesday, 23 February 2021 \\
\hline ACCEPTED ON & (cc) EY \\
\hline LICENSE & Lis work is licensed under a Creative Commons Attribution 4.0 International \\
\hline JOURNAL & "Economics of Development" \\
\hline ISSN PRINT & $1683-1942$ \\
\hline ISSN ONLINE & $2304-6155$ \\
\hline PUBLISHER & LLC “Consulting Publishing Company "Business Perspectives" \\
\hline FOUNDER & Simon Kuznets Kharkiv National University of Economics \\
\hline
\end{tabular}

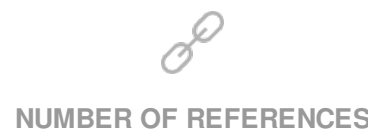

27
NUMBER OF FIGURES

5

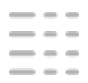

NUMBER OF TABLES

4

(C) The author(s) 2021. This publication is an open access article. 


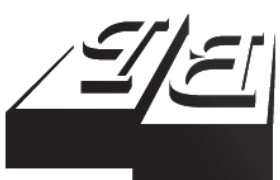

BUSINESS PERSPECTIVES

Publisher

LLC "CPC "Business Perspectives" Hryhorii Skovoroda lane, 10, Sumy, 40022, Ukraine www.businessperspectives.org

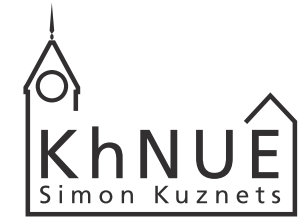

\section{S. KUZNETS KHNUE}

Founder

Simon Kuznets Kharkiv National University of Economics, Nauky avenue, 9-A, Kharkiv, 61166,

Ukraine

http://www.hneu.edu.ua/

Received on: 25th of November, 2020 Accepted on: 23rd of February, 2021 Published on: 20th of August, 2021

(c) Musdalifah Azis,

Michael Hadjaat, Rositawati,

Dio Caisar Darma, 2021

Musdalifah Azis, Lecturer, Department of Management, Faculty of Economics and

Business, Mulawarman University, Indonesia.

Michael Hadjaat, Lecturer, Department of Management, Faculty of Economics and

Business, Mulawarman University, Indonesia.

Rositawati, Student, Department of Management, Faculty of

Economics and Business,

Mulawarman University,

Indonesia.

Dio Caisar Darma, Researcher, Department of Management, Sekolah Tinggi Ilmu Ekonomi Samarinda, Indonesia.

\section{(c) (i)}

This is an Open Access article, distributed under the terms of the Creative Commons Attribution 4.0 International license, which permits unrestricted re-use, distribution, and reproduction in any medium, provided the original work is properly cited.
Musdalifah Azis (Indonesia), Michael Hadjaat (Indonesia), Rositawati (Indonesia), Dio Caisar Darma (Indonesia)

\section{EVALUATION OF SYSTEMATIC RISK, CORPORATE GOVERNANCE, AND CASH HOLDINGS: EVIDENCE FROM INDONESIA}

\begin{abstract}
Profits that are calculated to finance unexpected cash need expedite management. This paper investigates the effect of corporate governance on cash holdings with systematic risk as a moderating variable. The population consists of companies from the property and real estate sectors listed on the Indonesia Stock Exchange (IDX) during 2012-2020. Through the purposive sampling technique, the sample obtained 41 companies as the study object. Data analysis is focused on panel data and its interpretation through the Moderated Regression Analysis (MRA). Hypothesis testing uses statistical terms at the $5 \%$ probability level. Important findings underline that corporate governance has a positive significant effect on cash holdings, while systematic risk has a negative insignificant effect. On the other hand, the moderation between corporate governance and cash holdings through systematic risk is positive significant. Systematic risk reflects the reliability of a stock; when the risk is higher, it tends to increase in cash flow situations, and investors prefer high-risk investments with the expectation of profit from returns. It is hoped that future contributions will serve as reference material for academics, government, and companies engaged in the financial service sector.
\end{abstract}

\section{Keywords \\ stock portfolio, financial risk, investment management, MRA, Indonesia}

JEL Classification

G11, G32, C24, G1

Мусдаліфа Азіс (Індонезія), Майкл Хаджаат (Індонезія), Росітаваті (Індонезія), Діо Кайсар Дарма (Індонезія)

\section{ОЦІНКА СИСТЕМАТИЧНИХ РИЗИКІВ, КОРПОРАТИВНОГО УПРАВЛІННЯ І ГОТІВКОВІ ЗАОЩАДЖЕННЯ: ДАНІ 3 ІНДОНЕЗІї}

\begin{abstract}
Анотація
Прибутки, які розраховані для фінансування непередбачених готівкових коштів, особливо потребують прискорення управління. Ця робота спрямована на вивчення впливу корпоративного управління на грошові кошти з систематичним ризиком як регулюючої змінної. Населення орієнтоване на сектори власності і нерухомості, включені в список Фондової біржі Індонезії на період 2012-2020рр. Методом цілеспрямованої вибірки в якості об’єкта дослідження було обрано 41 компанію. Аналіз даних в цьому дослідженні зосереджений на групових даних і їх інтерпретації за допомогою помірного регресійного аналізу (ПРА). При перевірці гіпотез використовуються статистичні терміни 3 5-відсотковим рівнем імовірності. Важливі висновки підкреслюють, що корпоративне управління надає позитивно-значущий вплив на готівкові кошти, в той час як систематичний ризик чинить негативний-незначний вплив. Відповідно до іншого результату, поміркованість між корпоративним управлінням та грошовими коштами через систематичний ризик $є$ позитивно-значною. Систематичний ризик відображає надійність акції, де ризик вище, він має тенденцію до збільшення в ситуаціях з грошовими потоками, а інвестори вважають за краще інвестиції з високим ризиком, 3 очікуванням прибутку від повернення. Сподіваємось, що майбутні внески стануть довідковим матеріалом для науковців, уряду та компаній, що займаються сектором фінансових послуг.
\end{abstract}

Ключові слова портфель акцій, фінансовий ризик, управління інвестиціями, модераційний регресійний аналіз, Індонезія

Класифікація JEL $\quad$ G11, G32, C24, G1 


\section{INTRODUCTION}

It is highly important for every company to have cash, otherwise its operations cannot be performed properly. Cash holding is the cash in the hands or available to invest in the form of assets or assets smoothly physically (Gill \& Shah, 2012). But, holding cash in the company can both result in a profit and losses for the company. The need for cash is unexpected. On the other hand, in the number of which loads can create conflicts agency because the manager has the desire to gain domination over an investment decision the company as a basic interest self (Jensen, 1986; Azis et al., 2020).

Many researchers study of cash holding, but the results of their research work are inconsistent. Theoretically, corporate governance aims to overcome the problem of an agency that is a conflict of interest between managers and shareholders, because when a company's corporate governance is weak, there may increase conflict agency. Relevant studies related to corporate governance and cash holding have been highlighted by various researchers and produce a variety of evaluations (Cheung, 2016; Harford et al., 2008; Dittmar \& Mahrt-Smith, 2007; Khan et al., 2016).

Another research is to identify the effect of the systematic risk used with cash holdings. The presentation of systematic risk, also known as market risk, is the risk associated with changes as a whole that can be eliminated through diversification by investors. Related research shows a positive welfare relationship between the systematic risk used for cash holdings (Cheung, 2016). However, this point differs from Palazzo (2012) and Acharya et al. (2013), who suggest that the systematic risk used has a significant negative effect on cash holdings.

Weak corporate governance has had a systematic impact by putting in little cash and the IDX forced to undertake high agency fees, earning the nickname twelve small mortgage loan wallets. The agency fee results from a conflict of interest between calculating ratings and the agency. If in a company with weak corporate governance, it can reduce the cash value of the parent company. Cheung (2016) emphasizes that corporate governance has a positive effect on cash holding. The same thing happens if low systematic risk is used when a company plans to reduce the investors' interest in investing in the company so that it can reduce the value of the company holding cash (Muliadi et al., 2020). Then, there will be a positive relationship between the systematic risk used and cash holdings.

The relationship between corporate governance and cash holding has several positive effects, namely when corporate governance decreases, cash holding decreases as well. The same can be seen in the systematic risk used where the systematic risk used by banks has a positive impact on cash holdings. The systematic risk used can be a moderating effect on the corporate governance of cash holdings. The reduction in the systematic risk used will strengthen the effect of corporate governance on cash holdings (Acharya et al., 2013; Ikbal et al., 2020).

Based on the phenomenon and several previous studies, this study aims to investigate the effect of corporate governance on cash holding with systematic risk as a moderating variable with empirical studies for Indonesia. The contribution of this study is expected to be a reference material for further researchers, the government, and companies engaged in financial services. Several sections for this study are presented in a structured manner. In the first section, the introduction clearly outlined the background, problem statements, and objectivity of the paper. The second section provides a literature review, describing the basic theory related to variables and an empirical review based on several studies. In the third, the research method section, the sample size, data, and data processing techniques are illustrated. In the fourth section, the findings present descriptive statistics, the results of hypothesis testing based on the study objectives, and data interpretation. The fifth section provides a discussion to clearly demonstrate the results based on the statistical findings compared with several relevant studies, whether they are in line or contradictory, then a number of hypotheses can be found that have been accepted and rejected. The last section suggests conclusions consisting of a brief overview of empirical findings, the study weaknesses, and policy implications. 


\section{LITERATURE REVIEW}

The characteristics of companies' cash holding are broadly explained on the grounds of three basic theories, namely free cash flow, pecking order, and trade-off theory. Each of these theories is intended to clarify the review of the predictions of each theory (e.g. Ferreira \& Vilela, 2004; Ngoc et al., 2020). As additional information, Gill and Shah (2012) define cash holding as cash available to be invested or cash on hand in the form of physical assets and to be distributed to investors. Meanwhile, Gore (2009) illustrates that cash holding is the ratio between cash and cash equivalents to monthly interest expenses and operating expenses.

Cash holding is the ratio that compares the amount of cash and cash equivalents the company has with the number of assets the company obtains as a whole (Cai et al., 2016). The list of companies referred to here includes companies in the property and real estate enrolled in the Indonesia Stock Exchange in the period 2012-2020.

Corporate governance is a system where business directed and controlled describing the framework of regulations with the separation between a principal and an agent (Manzaneque et al., 2016). The agent mentioned is a board of directors, an appointed principal responsible for all cash management, corporate governance, and another policy in a sector property company and real estate listed in the Indonesian Stock Exchange for the period 2012-2020.

The systematic risk used is the risk that, considering the transformation that occurs in the market as a whole, may not be omitted through diversification in economic activities shown by investors. The research uses a 'beta' to describe the systematic risk of a securities or portfolio assessment became relatively against a risk its shares in companies in the research products which are and real of an estate enrolled in the Indonesia Stock Exchange between 2012 and 2016.

Corporate governance is a concept relating to maximizing shareholders' profit and protection from economic agents providing capital to a company. One of the main roles of corporate governance is dealing with an agency that represents a conflict of interests between managers and shareholders reasonable by weak governance management of excessive cash possession for their personal gain by investing in the net present value (NPV) negative. Because of this reason, this agency will weaken the conflict between the two sides (Jensen, 1986). Corporate governance is associated to cash holding as positively-significant if seen from the agency's perspective because of the company by the conflict agency high with weak governance which keeps less cash (Manzaneque et al., 2016).

Corporate governance associated with negative cash holding by significant to see motive agency cost because firms to governance bad cause agency cost was high and cause the ownership small, agency cost itself because of the conflict of interest between a principal and an agent (Cheung, 2016). It is not surprising that the companies that are complex with the agency conflict crucial height have a problem because the board of directors expresses a desire to build cash to self-interest and not employed in support shareholders.

The used systematic risk changes that occurr in the risks market can affect all companies. There are two views about the relationship between systematic risk and cash holding. The first point is that low systematic risk may reduce cash holdings to reduce motive transaction to keep cash which means systematic risk is associated to cash holding as positively-significant because the company with a low correlation with the shock of the aggregate tends to a shortage of cash flow in a situation where companies need (Palazzo, 2012). The other view is that systematic risk can affect the way of how a company chooses between cash and bank credits. Banks cannot guarantee liquidity for all the companies at any time and are inclined to grant a credit line to all companies at low systematic risk so small cash holding and thus systematic risk is associated with positive significance to cash holding (Acharya et al., 2013). 


\section{METHODS AND DATA}

The population in this research is all companies and real estate property sectors listed on the Indonesia Stock Exchange (IDX) for the period 2012-2020 that comprise about 41 property sector and real estate companies in total. The sampling technique applied in the research was based on the criteria upon (sampling purposive), with certain consideration fulfilled to sampling in Table 1.

Table 1. Sample criteria based on a purposive sampling technic

\begin{tabular}{l|c}
\multicolumn{1}{c}{ Criteria } & Source: Formed by the authors. \\
\hline Sector property and real estate companies listed in the Indonesia Stock Exchange for December 2016 & Total \\
\hline Sector property and real estate companies that failed to provide annual reports since the period 2012-2020 & 47 \\
Sample count & $(6)$ \\
\hline
\end{tabular}

Then, with the support of secondary data from the IDX website, the variables are presented according to 3 functions based on the study objectives. Two hypotheses are related to the analysis of systematic risk and corporate governance applied to cash holding. This involves systematic risk and corporate governance as independent variables, and cash holding is the dependent variable. For the third hypothesis, systematic risk becomes a moderating variable that affects the relationship between corporate governance and cash holding.

From this difference, Indriastuti et al. (2020) emphasize the position of the independent variable functions to predict the independent variable, while the dependent variable is the variable influenced or predicted by the independent variable. The two variables are still in the form of a one-way relationship. On the one hand, specifically for moderating variables like the previous case, it serves to weaken or strengthen the direct relationship between the independent variable and the dependent variable, which is played by systematic risk. As many as 41 samples based on the population have done filtering technique sampling purposive. The moderation research used a Moderated Regression Analysis (MRA), and the model received is as follows:

$C H_{i t}=\alpha+\beta 1 C G_{i t}+\beta 2 S R_{i t}+\beta 3 S R^{\star} C G_{i t}+e_{i t}$

where, $C H$ - cash holding, $\alpha$ - constant, $\beta$ - regression coefficient, $G G$ - corporate governance, $S R$ - systematic risk, ${ }^{\star}$ - multiplication of systematic risk and cash holdings, it - time series, and $e$ - error term.

The provisions of each variable clarify the size and scale used. To simplify the measurement of variables, we arrange the following scale and estimate from Table 2.

Table 2. Estimated of variables

Source: The IDX (2020)

\begin{tabular}{|c|c|c|c|c|}
\hline Variables & Code & Measurements & Scale & References \\
\hline Cash holding & $Y$ & $\begin{array}{l}\text { Cash holding = the ratio of cash and cash } \\
\text { equivalents / total assets }\end{array}$ & Ratio & Cai et al. (2016) \\
\hline Corporate governance & $x 1$ & Board size $=$ number of boards of directors & Ratio & Manzaneque et al. (2014) \\
\hline Systematic risk & $x 2$ & $C E=R F+\beta \times(M R-R F)^{*}$ & Ratio & Jogiyanto (2008) \\
\hline
\end{tabular}

Note:* - where, $C E$ - cost of equity, $R F$ - risk-free rate, $B$ - beta on non-diversifiable risk which cannot be eliminated through diversification by investors such as political factors and certain economic conditions), MR - market return for Indonesia using the Index Composite Share Price (IHSG).

This study's analysis model is the development of several previous studies that discuss the linkages of systematic risk, corporate governance, and cash holding that are listed by manufacturing companies (Ozordi et al., 2019; Tong, 2008; Ajanthan \& Kumara, 2017; Azis et al., 2020). 


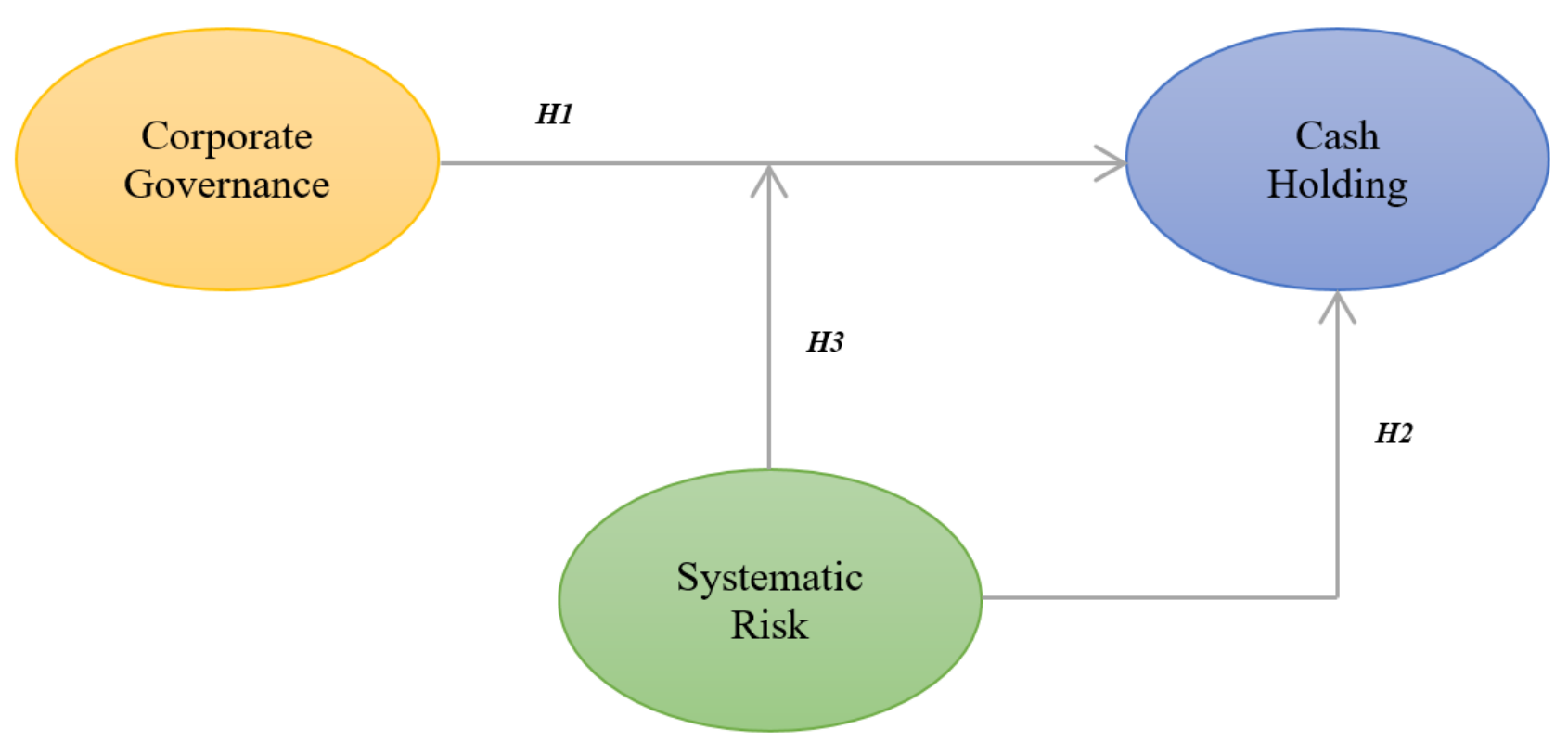

Source: Created by the authors.

Figure 1. Framework

Figure 1 illustrates the direct influence (corporate governance and systematic risk) on cash holding and the moderating effect of systematic risk on cash holding through the role of corporate governance. The hypothesis design and expected signs for this study are detailed as follows:

H1: It is assumed that there is a positively-significant relationship between corporate governance and cash holding.

H2: It is assumed that there is a positively-significant relationship between systematic risk and cash holding.

H3: It is assumed that there is a positively-significant relationship between systematic risk and moderate corporate governance and cash holdings.

\section{RESULTS}

In this section, we need to describe an overview of the study and statistical tests based on the proposed hypotheses. Referring to cash holding calculations to the property and real estate company as a sample of Indonesia stock exchange 2012-2020 period can be averaged from Figure 2.

Over the nine periods, the growth in cash holdings in property and real estate companies appeared inconsistent. The highest average cash holding value in the 2014 period was 0.128 . On the one hand, a decrease in the average cash holding value by 0.064 also occurred in 2020 , where a decrease in the cash holding value showed that the company was using excessive funding, so if the cash holding was low, it could result in the lack of ability to achieve the company's goals and missed investment opportunity.

As can be seen from Figure 3, the average value of corporate governance also fluctuates over nine periods. The peak increase in corporate governance value by companies for 2017 was 5.22. This shows that the higher the level of the company's compliance to maximize shareholder profits and protection from economic actors provides capital for the company. Meanwhile, the lowest corporate governance score was at the level of 4.93 in 2020.

With the current instability of corporate governance, the value shows that when a board size mean value experience a fall in means conflict agency higher and having an impact for a cash holding decreased level. While at the time of the board size average value increases, it indicates the increase in cash holding because corporate governance plays an important role in cash maintaining the level to do so from the company in shareholder support. 


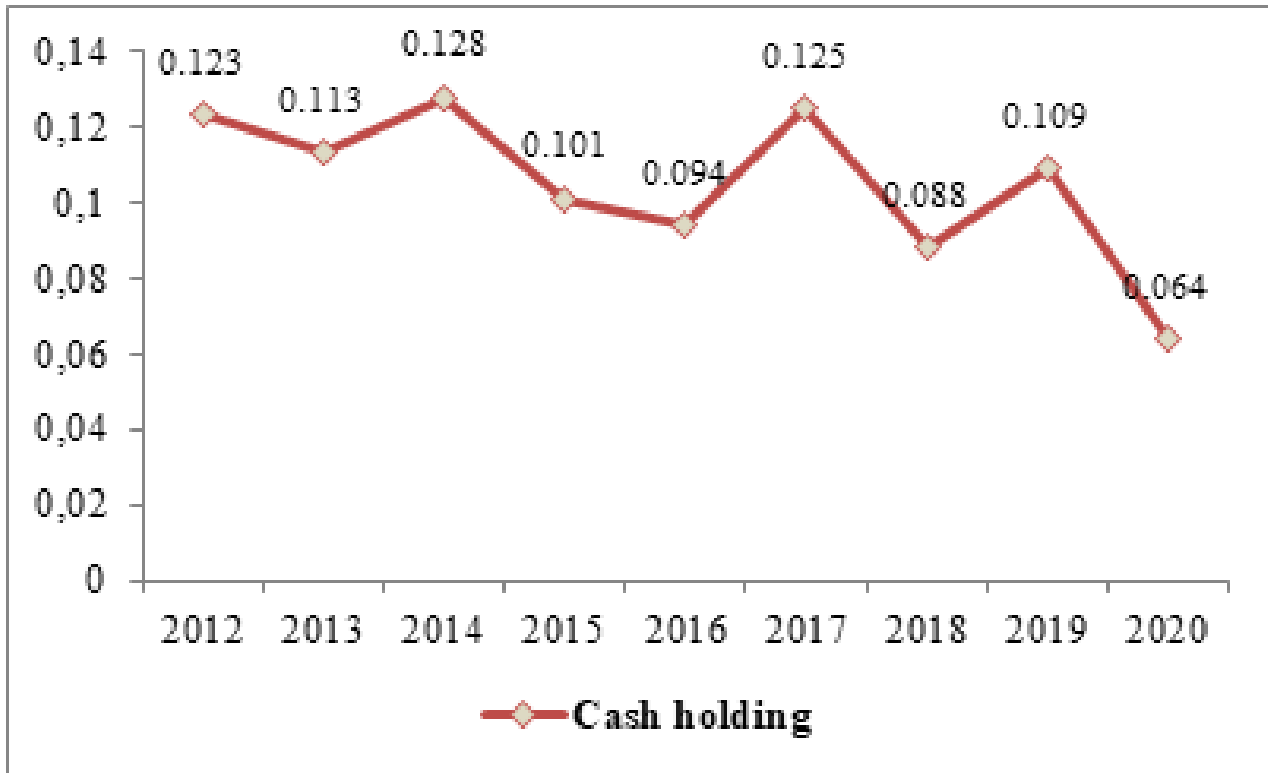

Source: Formed by the authors.

Figure 2. Cash holding average value of property and real estate sample companies in IDX

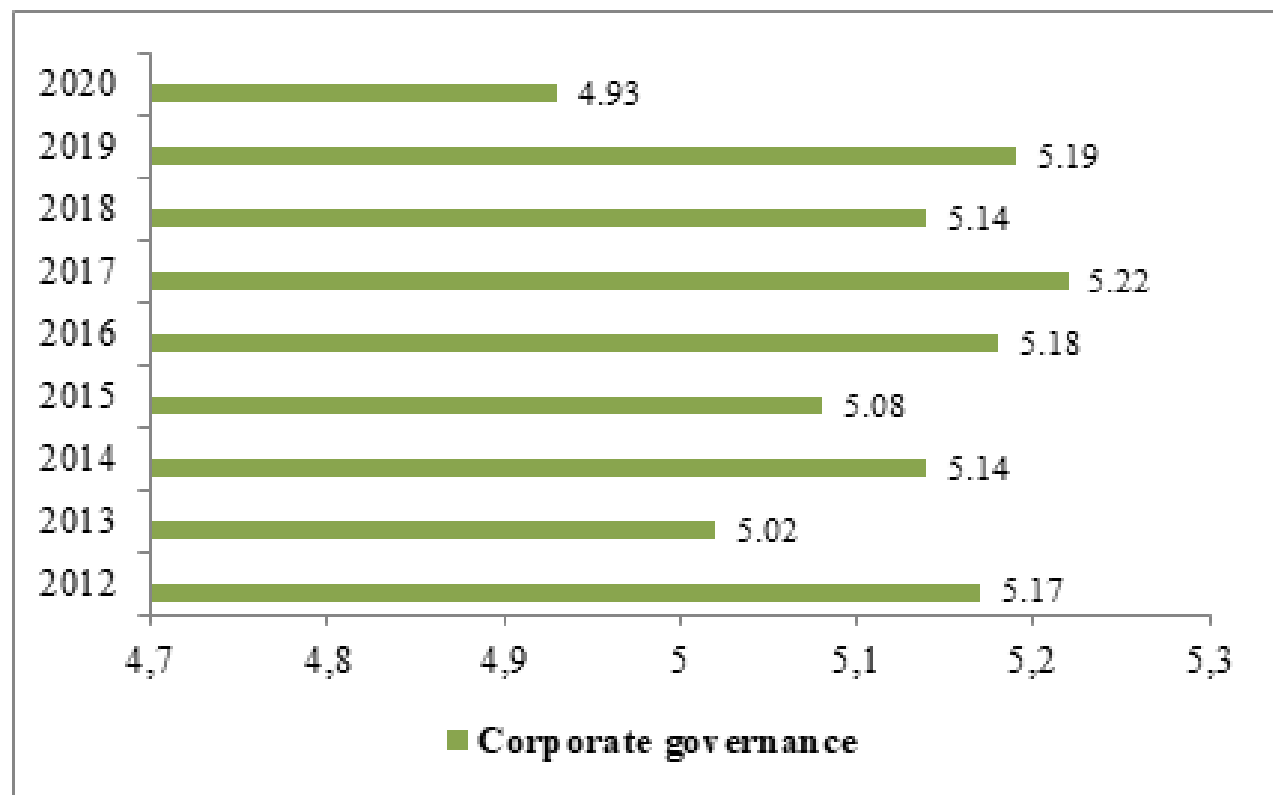

Source: Formed by the authors.

Figure 3. Corporate governance average value of property and real estate sample companies in IDX

A high-risk level of an investment company reflects the high rate of the expected return. Then we can conclude that investors always expect to benefit from investments but cannot be separated from them. The existing risk in this research to measure systematic risk value used a 'beta' measuring instrument because beta is a stage stock sensitivity towards affecting factor changes that occurred in the market. The findings are based on the beta value calculations of property and real estate companies (see Figure 4). In 2012, an achievement of 1.215 was a systematic risk position. Next, 2013 showed a dramatic increase, where the value reached 1.379 and the peak of the increase occurred in 2014 with 1.782 points. The increase in the mean value indicates a higher beta and a higher risk for taking any stock market risk. When a stock has a high beta, it reflects a high-risk stock. A fantastic decline was in 2016, where the average value of systematic risk was up to 0.590 . 


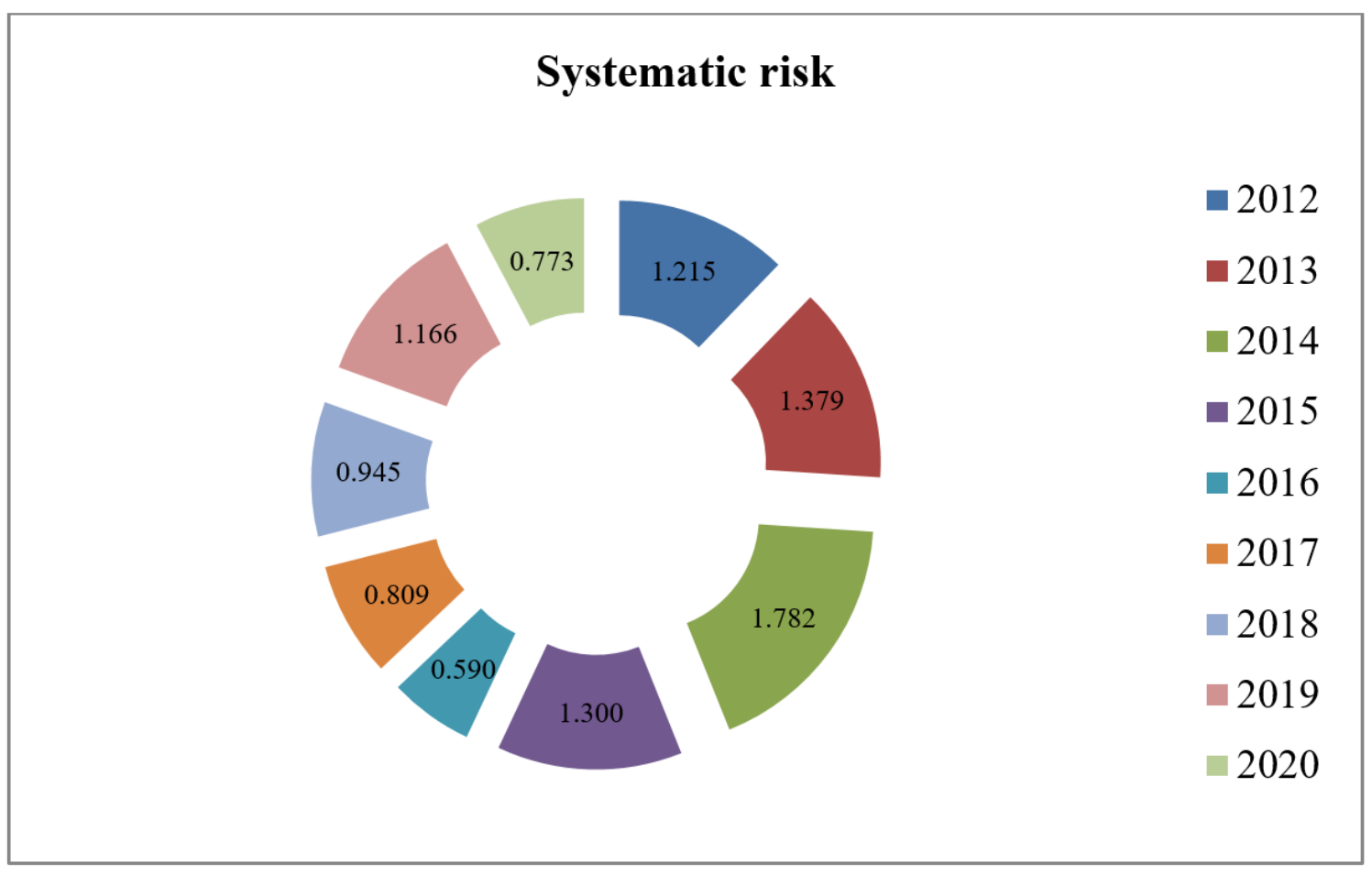

Source: Formed by the authors.

Figure 4. Systematic risk average value of property and real estate sample companies in IDX

To measure systematic risk, this research uses the tools measuring beta which is greatly affected by investment opportunities. Corporate governance is measured through board size as indicated as a board director of responsibility for all cash management, corporate governance, and another policy. If beta affects corporate governance, so corporate governance is multiplied by beta. This was done to see if there is a powerful relationship between corporate governance and systematic risk to cash holding.

Figure 5 confirms that the results of the moderating variables on corporate governance and systematic risk experience instability. The biggest peak was in 2014, where the average moderation value reached 9.159. 2016 was associated with the lowest period as property and real estate values reached the level of 3.056.

Spriestersbach et al. (2009) inform that descriptive statistics function to explain data, understand, and interpret an event that is collected on a particular object, investigation, and do not arrive at generalizations or conclusions about the observations being investigated. The distribution of data relating to the variables in this section is calculated through Table 3 including the mean, maximum, minimum, median, SD, skewness, and kurtosis with varying values.

Table 3. Review of descriptive statistics $(n=369)$

Source: Formed by the authors

\begin{tabular}{|c|c|c|c|c|}
\hline & CG & SR & $\mathrm{CH}$ & CGY \\
\hline Mean & 5.118 & 1.106 & 0.105 & 5.663 \\
\hline Maximum & 5.22 & 1.78 & 0.13 & 9.16 \\
\hline Minimum & 4.93 & 0.59 & 0.06 & 3.06 \\
\hline Median & 5.14 & 1.116 & 0.109 & 6.052 \\
\hline Std. Deviation (SD) & 0.093 & 0.366 & 0.020 & 1.876 \\
\hline Skewness & -1.189 & 0.429 & -0.877 & 0.444 \\
\hline Kurtosis & 0.833 & -0.020 & 0.460 & 0.082 \\
\hline
\end{tabular}




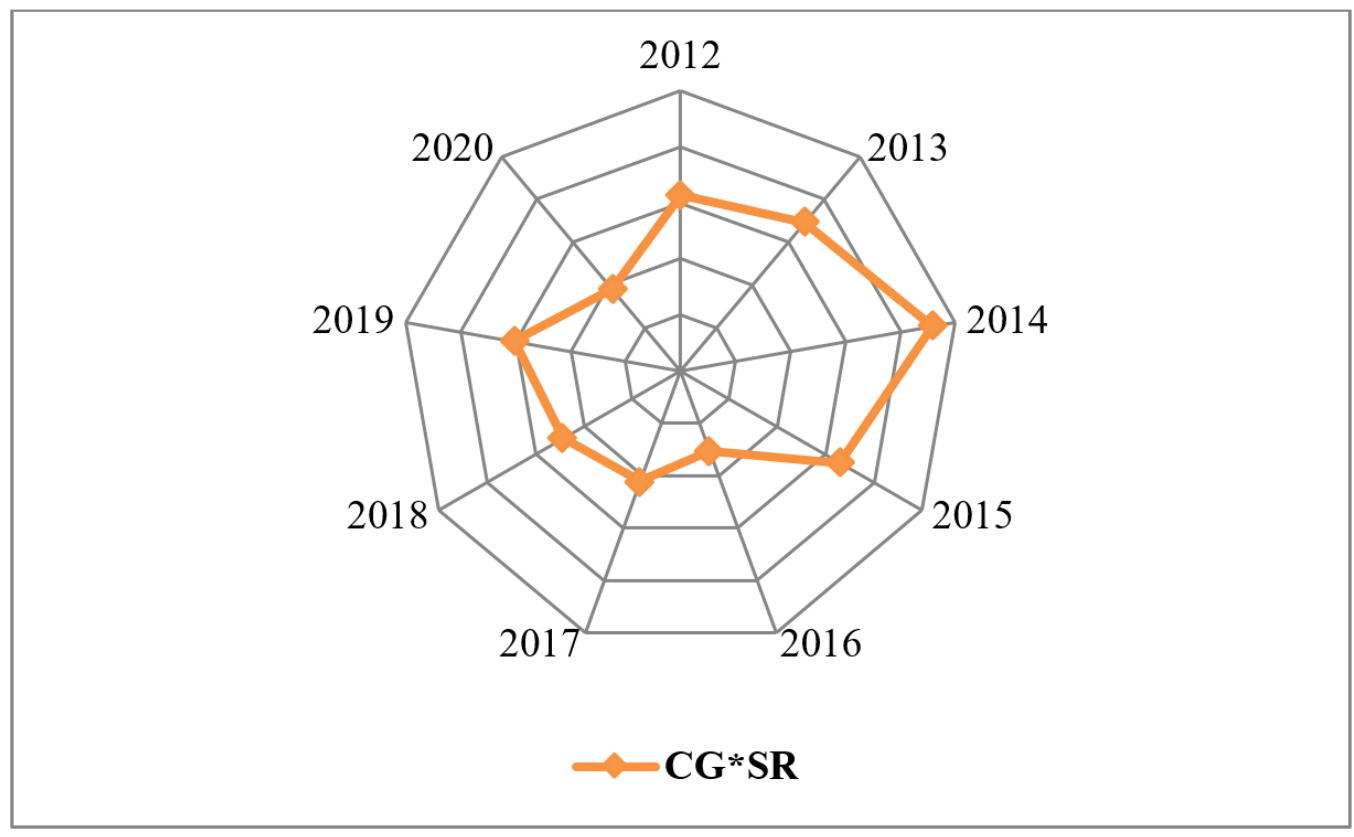

Source: Formed by the authors.

Figure 5. Moderation average value of property and real estate sample companies in IDX

The output on descriptive statistics evaluates that corporate governance has the highest mean, maximum, minimum, median, and kurtosis acquisition when compared to the other two variables. For primary achievement and skewness, it is precisely the systematic risk that is greatest. In contrast to cash holding, the overall score in the descriptive statistical component is the lowest. Moderation of corporate governance using systematic risk (beta) proved to be positive, where the standard deviation was quite high at 1.876 and the maximum value reached 9.16.

Table 4. Data panel regression analysis

Source: Formed by the authors.

\begin{tabular}{|c|c|c|c|c|c|c|}
\hline & Coeff. & Std. Error & t-Statistic & Prob. & Direction & Conclusion \\
\hline (Constant) & 0.255 & 0.069 & 5.490 & $0.017<0.05$ & & - \\
\hline CG & 1.528 & 0.038 & 4.184 & $0.033<0.05$ & $(+)$ & Accepted \\
\hline SR & -0.146 & 0.078 & -1.328 & $0.304>0.05$ & $(-)$ & Rejected \\
\hline$C G^{*} S R$ & 2.763 & 0.169 & 3.142 & $0.026<0.05$ & $(+)$ & Accepted \\
\hline $\mathrm{R}$ & 0.964 & & & & & \\
\hline $\mathrm{R} 2$ & 0.929 & & & & & \\
\hline F-Statistic & 2.876 & & & & & \\
\hline F-Sig. & 0.025 & & & & & \\
\hline
\end{tabular}

Note: $p<0.05$

Simultaneous testing ensures that the three recommended variables (corporate governance, systematic risk, and cash holding) have a significant impact, where the coefficient is a constant of 0.255 with a probability of 0.017 or the level of significance is greater than the F-statistic. Overall, the proposed model is feasible or has met the assumptions based on statistical criteria because the correlation (R) is classified as very close and the coefficient of determination $\left(\mathrm{R}^{2}\right)$ reaches $92.9 \%$. That is, $7.1 \%$ are other variables outside the study model or may be considered a residual factor.

Furthermore, for partial and moderation testing based on Table 4, it appears that the results are very different from the previous ones. Corporate governance has a positively-significant effect on cash holding, whereas systematic risk has a negatively-significant impact on cash holding. Interestingly, the relationship between corporate governance and cash holding is moderated by systematic risk; the result is positively-significant so that systematic risk is a variable that is considered appropriate in influencing the two relationships. Brief explanations of the 
achievements in each hypothesis, interpreted by corporate governance on cash holding are p-value $<0.05$, systematic risk and cash holding are indicated by $p$-value $>0.05$, then systematic risk on corporate governance and cash holding is obtained amounting to $0.026<0.05$. The probability level used as a standard in this model is $5 \%$.

\section{DISCUSSIONS}

With EViews 8, it can be seen that the systematic risk variable used as a moderating variable (a type of moderation potential) can affect the relationship between corporate governance and cash holding, or the third hypothesis is accepted.

The findings highlight the moderation between the systematic risk used and corporate governance that has had a significant impact on the sustainability of cash holding. In addition, these results are in line with the hypothesis that has been developed, in which systematic risk has played a significant role as a moderating variable that strengthens the relationship between corporate governance and cash holding. This also reflects the fact that through systematic risk, investors can get profit now to predict future profits and income. If the investor is at risk of the company's windfall income, the future profit is also lower. Thus, if the point is high, corporate governance beta will also increase and will cause the effect of systematic risk which is used as a moderating variable on corporate governance to increase rapidly and its effect on cash holdings is very close. Based on significant achievements, it may be assumed that, in general, companies contain the same pattern.

These results also present several previous studies discussing the close relationship between systematic risk, corporate governance, and holding. The government allows managers to control cash flow to avoid under-investment and plays a monitoring role in regulating industry behavior. According to Hsu et al. (2014), this corresponds to the size of the independent director's responsibility because it aims to monitor the manager's cash expenditure behavior and avoid investment restrictions.

Cash owned by investors plays an important role in companies' policy, and even acts as the most significant thing. The dramatic increase in cash reserves, despite alternative instruments such as debt, derivatives, and lines of credit. Financial behavior is the subject of a discussion as a determinant of cash holding and various reasons for companies to save cash. A systematic understanding of cash holding in the financial sector certainly becomes the main focus to determine the direction of a company's sustainability (Cruz et al., 2019).

Corporate cash holding has grown rapidly throughout the world so far. As a result, various studies have highlighted and examined cash holding based on company's results and company's values. The effectiveness and efficiency of various corporate governance tools to limit cash holding are important because these factors prove to be fundamental for investor's confidence in the fact that cash will not be wasted. The measurement scale associated with the empirical cash holding study is closely related and has always been an interesting issue to be discussed (Amess et al., 2015).

\section{CONCLUSIONS}

This research made three significant points. First, corporate governance has a positive and powerful impact on cash held by property and real estate companies. It is in line with the proposed hypothesis, that corporate governance has a positively-significant effect on cash holdings. The relevance of agency theory seen from an agency perspective includes the problem of companies with high agency conflicts with weak corporate governance reducing cash holdings. Secondly, the systematic risk used has a negative and significant effect on cash holdings. As the systematic risk used can be understood as the risk of a stock, where a higher risk tends to increase in cash flow situations, investors prefer high-risk investments with large returns. Thirdly, the systematic risk that is used as a moderating variable (moderation type) can affect the potential for corporate governance in holding cash. There is an agreement with moderation through the systematic risk that is evaluated so that corporate governance has a significantly positive relationship with cash holdings. 
Based on the limitations and weaknesses that refer to the presentation results, we suggest that future studies should consider other aspects related to the weak moderation of systematic risk in its effects on corporate governance and cash storage. In general, the focus on the value of corporate governance, systematic risk, and cash holding for 2020 is below average when compared to other periods. As is well known, the effects of Covid-19 have triggered global problems, including financial markets. Falling share prices in various countries triggered drastic declines in a number of sectors and had a strong impact on the macroeconomy. Thus, the relevant dimensions have attracted attention and can be a reference for future insight.

\section{ACKNOWLEDGEMENTS}

The authors are grateful to the Editor of "Economics of Development" for guidance during the submission process. In addition, we also declare no conflict of interest, and the contribution of this study is intended for the public interest.

\section{AUTHORS CONTRIBUTIONS}

Conceptualization: Michael Hadjaat.

Data curation: Musdalifah Azis.

Formal Analysis: Michael Hadjaat.

Funding acquisition: Dio Caisar Darma.

Investigation: Michael Hadjaat.

Methodology: Musdalifah Azis.

Project administration: Rositawati.

Resources: Michael Hadjaat.

Software: Rositawati.

Supervision: Michael Hadjaat.

Validation: Rositawati.

Visualization: Dio Caisar Darma.

Writing - original draft: Musdalifah Azis, Dio Caisar Darma.

Writing - review \& editing: Rositawati, Dio Caisar Darma.

\section{REFERENCES}

1. Acharya, V., Almeida, H., \& Campello, M. (2013). Aggregate risk and the choice between cash and lines of credit. The Journal of Finance, 68(5), 2059-2116. https://doi.org/10.1111/jofi.12056

2. Ajanthan, A., \& Kumara, K. (2017). Corporate governance and cash holdings: empirical evidence from an emerging country, Sri Lanka. International Journal of Accounting and Financial Reporting, 7(2), 112-128. https://doi.org/10.5296/ijafr.v7i2.12137

3. Amess, K., Banerji, S., \& Lampousis, A. (2015). Corporate cash holdings: causes and consequences. International Review of Financial Analysis, 42, 421-433. https://doi.org/10.1016/j.irfa.2015.09.007

4. Azis, M., Amalia, S., \& Darma, D. (2020). Information asymmetry, government ownership, and dividends from the building construction from Indonesia. Journal of Scientific Papers: Social Development and Security, 10(6), 3-8. https://doi.org/10.33445/sds.2020.10.6.1

5. Azis, M., Hidayati, T., \& Adhimursandi, D. (2020). Corporate social responsibility and good corporate governance toward to equity return in banking: empirical from Indonesia. International Journal of Advanced Science and Technology, 29(3), 9525-9531. Retrieved from http:// sersc.org/journals/index.php/IJAST/article/view/26878

6. Cai, W., Zeng, C., Lee, E., \& Ozkan, N. (2016). Do business groups affect corporate cash holdings? evidence from a transition economy. China Journal of Accounting Research, 9(1), 1-24. https://doi.org/10.1016/j.cjar.2015.10.002

7. Cheung, A. (2016). Corporate social responsibility and corporate cash holdings. Journal of Corporate Finance, 37, 412-430. https://doi. org/10.1016/j.jcorpfin.2016.01.008

8. Cruz, A., Kimura, H., \& Sobreiro, V. (2019). What do we know about corporate cash holdings? A systematic analysis. Journal of Coorporate \& Finance, 30(10), 77-143. https://doi.org/10.1002/jcaf.22368 
9. Dittmar, A., \& Mahrt-Smith, J. (2007). Corporate governance and the value of cash holdings. Journal of Financial Economics, 83(3), 599-634. https://doi.org/10.1016/j.jfineco.2005.12.006

10. Ferreira, M., \& Vilela, A. (2004). Why do firms hold cash? Evidence from EMU countries. European Financial Management, 10(2), 295-319. https://doi.org/10.1111/j.1354-7798.2004.00251.x

11. Gill, A., \& Shah, C. (2012). Determinants of corporate cash holdings: evidence from Canada. International Journal of Economics and Finance, 4(1), 70-79. http://dx.doi.org/10.5539/ijef.v4n1p70

12. Gore, A. (2009). Why do cities hoard cash? Determinants and implications of municipal cash holdings. The Accounting Review, 84(1), 183-207. http://dx.doi.org/10.2139/ssrn.913425

13. Harford, J., Mansi, S., \& Maxwell, W. (2008). Corporate governance and firm cash holdings in the US. Journal of Financial Economics, 87(3), 535-555. https://doi.org/10.1016/j.jfineco.2007.04.002

14. Hsu, W., Huang, Y., \& Lai, G. (2014). Corporate governance and cash holdings: evidence from the U.S. property-liability insurance industry. The Journal of Risk and Insurance, 82(3), 715-748. https://doi.org/10.1111/jori.12049

15. IDX (2020). Daftar saham (List of shares). Retrieved from https://www.idx.co.id/data-pasar/data-saham/daftar-saham

16. Ikbal, M., Irwansyah, I., Paminto, A., Ulfah, Y., \& Darma, D. (2020). Explores the specific context of financial statement fraud based on empirical from Indonesia. Universal Journal of Accounting and Finance, 8(2), 29-40. https://doi.org/10.13189/ujaf.2020.080201

17. Indriastuti, H., Kasuma, J., Zainurossalamia, S., Darma, D., \& Sawangchai, A. (2020). Achieving marketing performance through acculturative product advantages: the case of sarong Samarinda. Asian Journal of Business and Accounting, 13(1), 241-261. https://doi. org/10.22452/ajba.vol13no1.9

18. Jensen, M. (1986). Agency costs of free cash flow, corporate finance, and takeovers. The American Economic Review, 76(2), 323-329. http:// dx.doi.org/10.2139/ssrn.99580

19. Jogiyanto, J. (2008). Analisis dan desain sistem informasi: pendekatan terstruktur, teori, dan praktek aplikasi bisnis [Information systems analysis and design: structured approaches, theory, and practice of business applications]. Yogyakarta: Andi.

20. Khan, A., Bibi, M., \& Tanveer, S. (2016). The impact of corporate governance on cash holdings: a comparative study of the manufacturing and service industry. Journal Financial Studies, 20(3), 40-79. Retrieved from https://econpapers.repec.org/article/vlsfinstu/ v_3a20_3ay_3a2016_3ai_3a3_3ap_3a40-79.htm

21. Manzaneque, M., Priego, A., \& Merino, E. (2016). Corporate governance effect on financial distress likelihood: Evidence from Spain. Revista de Contabilidad, 19(1), 111-121. https://doi.org/10.1016/j.rcsar.2015.04.001

22. Muliadi, M., Darma, D., \& Kasuma, J. (2020). MSMEs as mediation in the effects of investment credit, interest rates, and labor on economic growth: evidence from Indonesia. International Journal of Finance \& Banking Studies, 9(2), 1-12. https://doi.org/10.20525/ijfbs. v9i2.702

23. Ngoc, H., Thuy, V., \& Duy, H. (2020). The sensitivity of cash flows to cash holdings: case studies at Vietnamese enterprises. Investment Management and Financial Innovations, 17(1), 266-276. http://dx.doi.org/10.21511/imfi.17(1).2020.23

24. Ozordi, E., Adetula, D., Eluyela, D., Aina, A., \& Ogabi, M. (2019). Corporate dynamism and cash holding decision in listed manufacturing firms in Nigeria. Problems and Perspectives in Management, 17(4), 1-12. https://doi.org/10.21511/ppm.17(4).2019.01

25. Palazzo, B. (2012). Cash holdings, risk, and expected returns. Journal of Financial Economics, 104(1), 162-185. https://doi.org/10.1016/j. jfineco.2011.12.009

26. Spriestersbach, A., Röhrig, B., du Prel, J., Gerhold-Ay, A., \& Blettner, M. (2009). Descriptive statistics: the specification of statistical measures and their presentation in tables and graphs. Deutsches Arzteblatt International, 106(36), 578-583. https://doi.org/10.3238/arztebl.2009.0578

27. Tong, Z. (2008). Firm diversification and the value of corporate cash holdings. Journal of Corporate Finance, 17(3), 741-758. https://doi. org/10.1016/j.jcorpfin.2009.05.001 